\title{
A rare cause of recurrent massive post-tonsillectomy bleed: facial artery pseudoaneurysm
}

\author{
Rzadka przyczyna rozległego krwawienia po zabiegu tonsillektomii: \\ tętniak rzekomy tętnicy twarzowej
}

\author{
'Department of Otorhinolaryngology, Hospital Segamat, Johor, Malaysia \\ ${ }^{2}$ Department of Interventional Radiologist, Hospital Kuala Lumpur, Malaysia \\ ${ }^{3}$ Department of Otorhinolaryngology - Head \& Neck Surgery, School of Medical Sciences, Universiti Sains Malaysia Health Campus, Kelantan, Malaysia \\ Correspondence: Dr Irfan Mohamad, Associate Professor, Department of Otorhinolaryngology - Head \& Neck Surgery, School of Medical Sciences, Universiti Sains Malaysia Health Campus, 16150 Kelantan, \\ Malaysia, tel:: 609-7676420, fax: 609-7676424, e-mail: irfankb@usm.my
}

Abstract Post-tonsillectomy haemorrhage is a potentially serious and sometimes fatal complication. It is commonly caused by infection or premature separation of membrane granulation tissue. Conventional haemostatic measures, such as ice water gargles, electrocautery or surgical ligation, usually will control the bleeding. We report a case of a delayed recurrent massive post-tonsillectomy bleeding resistant to usual measures, which required external carotid ligation. Computed tomography angiogram performed later revealed a pseudoaneurysm of the facial artery, which was successfully controlled with endovascular embolisation of the left facial artery.

Keywords: recurrent post-tonsillectomy bleeding, pseudoaneurysm, facial artery

Streszczenie Krwotok po zabiegu tonsillektomii to potencjalnie poważne, a niekiedy śmiertelne powikłanie. Jego częstym powodem jest zakażenie lub przedwczesne odklejenie się ziarniny. Zahamowanie krwawienia zazwyczaj umożliwiają konwencjonalne metody hemostatyczne, takie jak płukanie wodą z lodem, kauteryzacja elektryczna lub podwiązanie chirurgiczne. W pracy przedstawiono przypadek odległego, nawracającego, rozległego krwawienia po zabiegu tonsillektomii, opornego na zwykle stosowane leczenie i wymagającego podwiązania tętnicy szyjnej zewnętrznej. W wykonanej następnie tomografii komputerowej naczyń krwionośnych uwidoczniono obecność tętniaka rzekomego tętnicy twarzowej. Przeprowadzono udaną embolizację wewnątrznaczyniową lewej tętnicy twarzowej.

Słowa kluczowe: nawracające krwawienie po zabiegu tonsillektomii, tętniak rzekomy, tętnica twarzowa 


\section{INTRODUCTION}

A lthough tonsillectomy is the most common otorhinolaryngological surgical intervention, it carries the risk of a fatal complication such as post-operative haemorrhage. The rates are between $0.28 \%$ and $20 \%^{(1)}$. Primary haemorrhage occurs intraoperatively or within 24 hours post-surgery, and can be controlled by pressure, ligation or electrocoagulation of the bleeding vessels. Secondary haemorrhage, which is usually seen between the days 5 and 10 after surgery, results from infection and early separation of membrane. Post-tonsillectomy haemorrhage can be secondary to formation of a pseudoaneurysm.

\section{CASE REPORT}

An 18-year-old male underwent bilateral tonsillectomy and adenoidectomy for recurrent tonsillitis. Adenotonsillectomy was performed uneventfully with the operative findings of bilateral grade III tonsillar hypertrophy and adenoid hypertrophy with no immediate intraoperative complications. The patient was discharged in a good condition after the operation. However, he presented to the emergency department with hypovolaemic shock secondary to oropharyngeal bleeding on day 10 after surgery. Haemoglobin $(\mathrm{Hb})$ level was $7.5 \mathrm{~g} / \mathrm{dL}$, requiring blood transfusion. His platelet count, prothrombin time and activated partial thromboplastin time were all within normal limits. Oropharyngeal inspection showed minimal blood clot in the left tonsillar region, but no active bleeding. He was admitted for observation and discharged after 2 days. The working diagnosis at that time was secondary haemorrhage post tonsillectomy. However, he presented again 3 days later with massive active bleeding from the oral cavity with a few episodes of hematemesis. He was in a hypovolaemic shock and anaemic with $\mathrm{Hb}$ of $6.8 \mathrm{~g} / \mathrm{dL}$. Initial resuscitation was performed. He was intubated in the emergency department to protect the airway from aspiration.

Once the patient's vital signs stabilised, an examination under general anaesthesia was performed in the operating theatre. Active bleeding from the left tonsillar fossa was found. Initially, the haemorrhage was controlled for 10 minutes with electrocautery of the left tonsillar fossa, but the bleeding was still profuse in the same setting of examination under anaesthesia (EUA). Therefore, packing of the tonsillar fossa was done, but haemostasis was not achieved. Thereafter, haemostatic suture was applied, but failed. Left external carotid artery (ECA) ligation above the superior thyroid artery level was performed due to the failure of all other haemostatic methods. No more bleeding occurred at left tonsillar fossa after left ECA ligation. There was inflammation and granulation tissue in the left tonsillar fossa with no evidence of deep dissection or extensive eschar from the initial tonsillectomy. The patient was discharged in a good condition after five days post-operatively. Ten days later, he reported to the emergency department with sudden onset of haematemesis

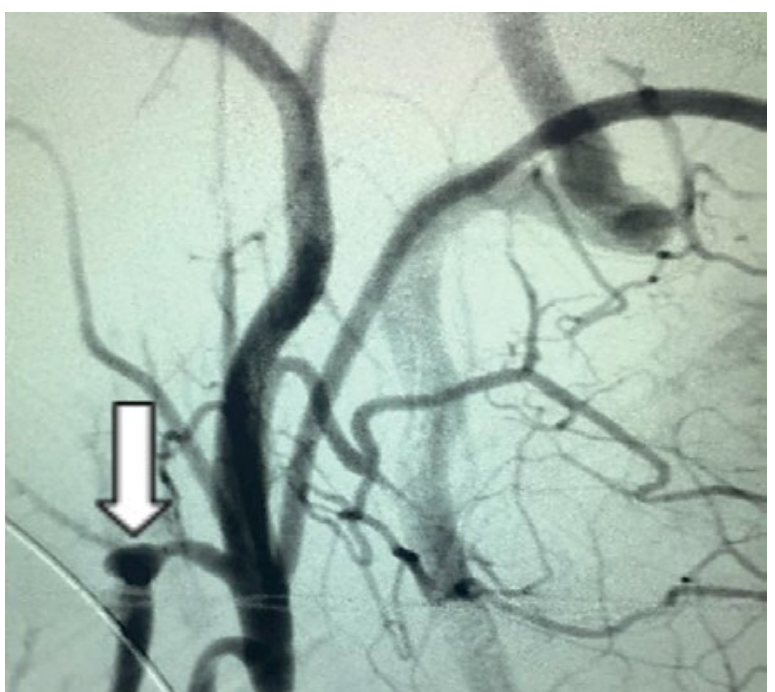

Fig. 1. Computed tomography angiogram of carotid arteries demonstrating a small pseudoaneurysm arising from the left facial artery

at home. Upon arrival, he was hypovolaemic and developed tachycardia. His vital signs improved after fluid resuscitation and blood transfusion. Oropharyngeal inspection showed minimal blood clot at the left tonsillar fossa. Iced water gargle was given and the active bleeding stopped. In view of recurrent nature of the bleeding, computed tomography angiogram of carotid arteries was done, demonstrating a small pseudoaneurysm arising from left facial artery with no active bleeding (Fig. 1). The lesion was successfully embolised with histoacryl $30 \%$ and haemostasis was achieved.

Post embolisation angiogram showed complete occlusion of the aneurysm as well as ostium of facial artery. The rest of branches of the external carotid artery remained well opacified (Fig. 2). No immediate complications occurred.

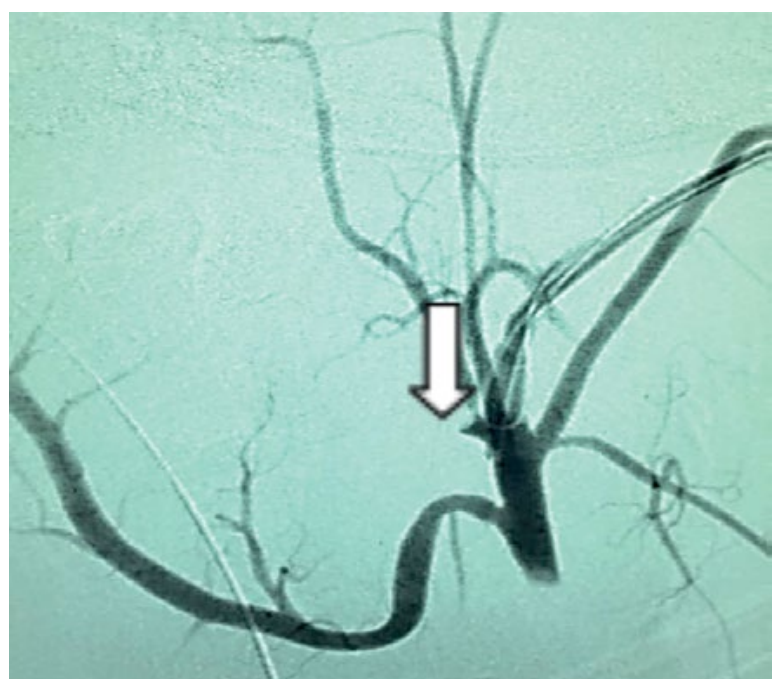

Fig. 2. Post embolisation angiogram showed complete occlusion of the aneurysm as well as the ostium of the facial artery. The rest of branches of the external carotid artery remained well opacified 
He was observed for 48 hours and remained asymptomatic. The patient was discharged home in a good overall condition. At one month clinic follow-up after embolisation, the patient was feeling well and there was no more recurrence of the oropharyngeal bleeding.

\section{DISCUSSION}

Post-tonsillectomy haemorrhage is a potentially serious and sometimes fatal complication. In cases when convenient haemostatic measures, such as ice water gargles, and surgical control of bleeding with electrocautery fail, computed tomography angiogram should be performed to further delineate the cause of the haemorrhage. Endovascular embolisation should be performed if indicated. Although uncommon, post-tonsillectomy pseudoaneurysms of the carotid artery and its branches are clinically significant lesions ${ }^{(2)}$. In fact, this is the first case of a post-tonsillectomy facial artery pseudoaneurysm reported in Malaysia. Moreover, so far only few other similar cases have been reported in Asia, Egypt, Europe and United States ${ }^{(3)}$. On the other hand, lingual artery pseudoaneurysms have been more frequently reported as a source of haemorrhage as compared to the facial $\operatorname{artery}^{(4)}$.

Pathophysiologically, pseudoaneurysms may develop after localised arterial laceration caused by either penetrating or blunt injury. Luminal blood outflows through the lacerated arterial wall into the surrounding soft tissues, and then creates a pseudoaneurysm sac that communicates directly with the arterial lumen ${ }^{(5)}$. Arterial injury can occur due to anatomic diversity of the great arteries and their close relation to the tonsil, as well as the presence of rich arterial supply to the palatine tonsils. The arterial supply includes the descending palatine artery, the ascending pharyngeal artery, the dorsal lingual artery, and the ascending palatine artery and tonsillar artery originating from the facial artery ${ }^{(6)}$.

Pseudoaneurysms can develop immediately post trauma, which can be identified within minutes of a haemorrhage during tonsillectomy or it may occur by slowly and gradually enlarging and be identified later, as in our case ${ }^{(7)}$. Numerous cases of pseudoaneurysm-related haemorrhage have been reported in the range of 1-3 weeks post-tonsillectomy or even later ${ }^{(8)}$. Hence, it is possible that pseudoaneurysm is present without any early haemorrhages. It is therefore crucial to include pseudoaneurysm in the differential diagnosis for delayed post-tonsillectomy haemorrhage. Treatment options for post-tonsillectomy haemorrhage include local manoeuvres, such as iced water gargle, electrocautery, surgical ligation and endovascular embolisation. External carotid artery ligation can be performed in emergencies, such as life-threatening bleeds or expanding hematomas with failed local manoeuvres. However, the bleeding still occurred after ECA ligation in this case due to collateral circulation from the branches of the left costocervical trunk. In cases of recurrent post-tonsillectomy haemorrhage, endovascular embolisation has benefits over surgical ligation.
Endovascular treatment has three foremost advantages. The diagnostic evaluation can be proceeded with direct therapeutic intervention. It is more selective; and lastly this method involves a lower risk of damage and a lower risk of injury to the vagal and accessory nerves ${ }^{(4)}$. The possible complications of embolisation are ischaemic injury to surrounding tissues, extravasation of embolic material, accidental embolisation of other vessels, and vasospasm. Furthermore, it might require other additional procedures. In the case of hospitals with limited access to an interventional radiological centre, the patient's airway must be secured and vital signs stabilised prior to transfer to an appropriate facility for further treatment.

\section{CONCLUSION}

Although tonsillectomy is one of the most common procedures worldwide, otorhinolaryngologists should be aware of pseudoaneurysms as the possible cause of recurrent posttonsillectomy bleeding as it is life-threatening. The most common artery involved in pseudoaneurysm is the lingual artery, and, very rarely, the facial or linguo-facial trunk. In these cases of haemorrhage, angiography with endovascular embolisation is effective as it can be both diagnostic and therapeutic. Endovascular treatment is safe, selective and definite in managing recurrent post-tonsillectomy bleeding secondary to pseudoaneurysms.

\section{Conflict of interest}

The authors do not declare any financial or personal links to other persons or organisations that could adversely affect the content of this publication or claim rights thereto.

\section{References}

1. Szeremeta W, Novelly NJ, Benninger M: Postoperative bleeding in tonsillectomy patients. Ear Nose Throat J 1996; 75: 373-376.

2. Atmaca S, Belet U, Baris S: Post-tonsillectomy pseudoaneurysm of the linguofacial trunk: an ENT surgeon's nightmare. Int J Pediatr Otorhinolaryngol Extra 2012; 7: 12-14.

3. Juszkat R, Korytowska A, Łukomska $Z$ et al.: Facial artery pseudoaneurysm and severe bleeding after tonsillectomy - endovascular treatment with PVA particle embolization. Pol J Radiol 2010; 75: 88-91.

4. van Cruijsen N, Gravendeel J, Dikkers FG: Severe delayed posttonsillectomy haemorrhage due to a pseudoaneurysm of the lingual artery. Eur Arch Otorhinolaryngol 2008; 265: 115-117.

5. Karas DE, Sawin RS, Sie KC: Pseudoaneursym of the external carotid artery after tonsillectomy. A rare complication. Arch Otolaryngol Head Neck Surg 1997; 123: 345-347.

6. Opatowsky MJ, Browne JD, McGuirt WF Jr et al.: Endovascular treatment of hemorrhage after tonsillectomy in children. AJNR Am J Neuroradiol 2001; 22: 713-716.

7. Simoni P, Bello JA, Kent B: Pseudoaneurysm of the lingual artery secondary to tonsillectomy treated with selective embolization. Int J Pediatr Otorhinolaryngol 2001; 59: 125-128.

8. Windfuhr JP, Sesterhenn AM, Schloendorff G et al.: Post-tonsillectomy pseudoaneurysm: an underestimated entity? J Laryngol Otol 2010; 124: 59-66. 